\title{
Weed control in soybean (Glycine max L.) through resource management strategies and its influence on yield and nutrient uptake
}

\author{
Aradhana Bali ${ }^{*}$, B. R. Bazaya ${ }^{2}$ and Sandeep Rawal ${ }^{1}$ \\ ${ }^{1}$ Department of Agronomy, CCS Haryana Agricultural University, Hisar- 125004(Haryana), INDIA \\ ${ }^{2}$ Division of Agronomy, Sher-e-Kashmir University of Agricultural Sciences and Technology of Jammu- 180009 \\ (J\&K), INDIA \\ *Corresponding author. E-mail: baliaradhana13@gmail.com
}

Received: June 4, 2016; Revised received: December 15, 2016; Accepted: February 20, 2017

\begin{abstract}
A field experiment was conducted during kharif season of 2011 at Research Farm, Sher-e-Kashmir University of Agricultural Sciences and Technology, Chatha, Jammu to evaluate the effect of weed management practices on yield and nutrient uptake of soybean utilizing different resource management strategies. The lowest weed density and dry matter of weeds was recorded with hand weeding at 15 and 35 days after sowing (DAS) which was equally effective as imazethapyr @ $75 \mathrm{~g} \mathrm{ha}^{-1}$ (PoE) fb hoeing at 35 DAS and quizalofop-ethyl @ $40 \mathrm{~g} \mathrm{ha}^{-1}$ (PoE) fb hoeing at 35 DAS. All weed control treatments had significant effect on yield and nutrient uptake of soybean. Among the different weed control treatments, lowest N, P and K uptake by weeds were recorded in hand-weeding (15 and 35 DAS) which was statistically at par with imazethapyr @ $75 \mathrm{~g} \mathrm{ha}^{-1}$ $\mathrm{fb}$ hoeing at 35 DAS. The maximum uptake by seed and straw were recorded in weed free which was statistically at par with twice hand weeding at 15 and 35 DAS, imazethapyr @ $75 \mathrm{~g} \mathrm{ha}^{-1} \mathrm{fb}$ hoeing at 35 DAS and quizalofopethyl @ $40 \mathrm{~g} \mathrm{ha}^{-1} \mathrm{fb}$ hoeing at 35 DAS. The highest seed and straw yield of soybean was harvested with handweeding (15 and 35 DAS) followed by imazethapyr @ $75 \mathrm{~g} \mathrm{ha}^{-1} \mathrm{fb}$ hoeing at 35 DAS. For the first time, soybean crop has been introduced in Jammu region for research purpose. Weed management varies with agro-climatic conditions. The study would be helpful to understand weed menace in this particular climatic condition of Jammu and to manage them combinedly and efficiently.
\end{abstract}

Keywords: Nutrient uptake, Resource management, Soybean, Weed control, Yield

\section{INTRODUCTION}

Soybean (Glycine max L.) is a globally important oilseed crop. In India, it is grown on an area of 108.83 lakh ha with an annual production of 104.36 lakh million tones (SOPA, 2014). It is highly nutritive crop which is very useful to meet the nutritional requirement of the escalating population but, being a rainy season crop soybean faces severe weed competition during early stages of crop growth, resulting in a loss of about 40-60 per cent of the potential yield, depending on the weed intensity, nature, environmental condition and duration of weed competition. Besides, weed removes 30-60 kg nitrogen, 8-10 kg phosphorous and 40-100 kg potash per hectare from soil (Mishra et al., 2002). Use of herbicides not only controlled weeds, improved crop yield but also increased the availability of labor for other productive uses. Alone application of herbicides do not provide season long control of weeds. Therefore, combination of different weed management practices is a desired solution that aims at reducing the dosage of herbicide to be applied to soil in combination with mechanical weeding, which will help in managing weeds in a best way to sustain and boost the production of soybean.

\section{MATERIALS AND METHODS}

Study sites: A field experiment was conducted during kharif season of 2011 at Research Farm, Sher-eKashmir University of Agricultural Sciences and Technology, Chatha, Jammu. The soil was characterized as sandy-loam in texture and alkaline in reaction $(\mathrm{pH}$ 7.7). It was low in organic carbon content $(0.39 \%)$ and nitrogen $\left(240 \mathrm{~kg} \mathrm{ha}^{-1}\right)$ and medium in phosphorus $\left(12.12 \mathrm{~kg} \mathrm{ha}^{-1}\right)$ and high in available potassium $(134 \mathrm{~kg}$ $\left.\mathrm{ha}^{-1}\right)$. The experiment comprised of twelve treatments comprising weedy check, weed free, hand-weeding at 15 and 35 days after sowing (DAS), hoeing at 15 and 35 days after sowing, fluchloralin@1.0 kg ha ${ }^{-1}$ (PPI), pendimethalin@1.0 kg ha ${ }^{-1}$ (PRE), imazethapyr@ $100 \mathrm{~g} \mathrm{ha}^{-1}$ (PoE), quizalofop-ethyl@ $50 \mathrm{~g} \mathrm{ha}^{-1}$ (PoE), fluchloralin@0.75 kg ha $\mathrm{kg}^{-1}$ (PP) $f b$ hoeing at 35 days after sowing, pendimethalin@0.75 kg ha-1 (PRE) $f b$ hoeing at 35 days after sowing, quizalofop-ethyl@40 $\mathrm{g} \mathrm{ha}^{-1}$ (PoE) $f b$ hoeing at 35 days after sowing and imazethapyr@75 $\mathrm{g} \mathrm{ha}^{-1}$ (PoE) fb hoeing at 35 days 
after sowing.

Method of data collection: The experiment wasconducted in randomized block design with three replications. Basal dose of 20: 40: $20 \mathrm{~kg} \mathrm{ha}^{-1} \mathrm{~N}: \mathrm{P}: \mathrm{K}$ was applied. Soybean cultivar SL-525 (with 115-120 DAS maturity) was planted at $45 \mathrm{~cm}$ row spacing @ $62.5 \mathrm{~kg}$ $\mathrm{ha}^{-1}$ seed rate. Before planting soybean seeds were treated with bavistin@3 $\mathrm{g} \mathrm{kg}^{-1}$. The herbicide fluchloralin as pre-plant incorporation at two days before sowing, pendimethalin as pre-emergence at one day after sowing, quizalofop-ethyl and imazethapyr as post emergence were applied at 15 DAS. Quantity of water required for spraying (600 $\left.1 \mathrm{ha}^{-1}\right)$ was determined by calibration of sprayer. For nutrient uptake, plant and grain samples were oven dried at $60{ }^{\circ} \mathrm{C}$ for 48 hours. These samples were grinded and passed through 20 mesh sieve and analyzed for total nitrogen, phosphorus, and potassium content. The uptake by seed and straw was obtained by multiplying the respective content with their seed and straw yields. For weeds, the weed plants taken for dry matter accumulation at 30 , 60,90 DAS and at harvest were grinded to fine material and were analyzed. Nitrogen content was determined by Kjeldhal method (Subbaiah and Asija, 1956), phosphorus content by spectrophotometer (Olsen et al., 1954) and potassium content by flame photometer (Jackson, 1973). The total N, P and K uptake by weeds were determined using their dry weight multiplied by nitrogen, phosphorus and potassium content respectively.

\section{RESULTS AND DISCUSSION}

Weed density and dry matter: All the weed control treatments had a marked effect on weed density and dry weight of weeds as compared to weedy check at harvest (Table 1). Least weed population and weed dry matter was found in two hand weeding (15 and 35 DAS) which was at par with imazethapyr @ $75 \mathrm{~g} \mathrm{ha}^{-1}$ $f b$ one hoeing at 35 DAS and quizalofop-ethyl @ $40 \mathrm{~g}$ $\mathrm{ha}^{-1} \mathrm{fb}$ one hoeing at $35 \mathrm{DAS}$. The reduction may be due to the fact that the herbicides used were soil active that had influenced germination of weed and also controlled the early flushes of weeds while later flushes of weeds were controlled by one hoeing at 35 DAS. The finding correlates with the findings of Kumar and Das (2008) and Meena and Jadon (2009). Kumar and Das (2008) studied weedmanagement practices in soybean and revealed that two hand-weeding produced in lowest weed density and dry matter production as compared to alone application of imazethapyr. Meena and Jadon (2009) found that quizalof-ethyl (50 g/ha) + chlorimuron ethyl $(9 \mathrm{~g} / \mathrm{ha})$ as post-emergent significantly reduced population and weed density of grassy weeds in soybean crop.

Nutrient uptake by weeds and crop: The weedy check showed significantly higher uptake of nitrogen, phosphorus and potassium than rest of the treatments (Table 2). Among the different weed control treatments, lowest N, P and K uptake were recorded in hand-weeding (15 and 35 DAS) followed by imazethapyr @ $75 \mathrm{gha}^{-1} \mathrm{fb}$ hoeing at $35 \mathrm{DAS}$. It has been found that the herbicides used in combination with hoeing produced significantly better results than herbicides used alone as less nutrient uptake was found with integrated methods than herbicide applied alone. The reason might be the combination of hoeing at 35 DAS reduced weed dry matter at later stages thereby reducing uptake (Table 2). These results are in agreement with that of Vyas et al. (2003) and Kumar and Das (2008). Vyas et al. (2003) found that lower P and K uptake by weeds in pendimethalin@1.0 kg/ha + one hand weeding, while $\mathrm{N}$ uptake in 2 hoeing + one hand weeding treatment in soybean crop to suppress grassy weeds.Kumar and Das (2008) studied integrated weed management for system productivity and economics in soybean and concluded that two hand weedings proved most superior in terms of lowest nutrient uptake $(3.1 \mathrm{~kg} \mathrm{~K} / \mathrm{ha})$ by

Table 1. Effect of different weed management practices on weed density and weed dry matter at harvest in soybean.

\begin{tabular}{|c|c|c|}
\hline Treatments & Weed density $\left(\mathrm{m}^{-2}\right)$ & Weed dry weight $\left(\mathrm{g} \mathrm{m}^{-2}\right)$ \\
\hline Weedy check & $272.0(16.51)^{*}$ & $168.33(12.98)^{*}$ \\
\hline Weed free & $0.0(0.71)$ & $0.00(0.71)$ \\
\hline Hand weeding at $15 \& 35$ DAS & $10.0(3.18)$ & $36.90(6.11)$ \\
\hline Hoeing at $15 \& 35 \mathrm{DAS}$ & $39.0(6.26)$ & $38.67(6.25)$ \\
\hline Fluchloralin@1.0 $\mathrm{kg} \mathrm{ha}^{-1}$ (PPI) & $81.0(9.02)$ & $56.83(7.56)$ \\
\hline Pendimethalin@1.0 kg ha ${ }^{-1}(\mathrm{PE})$ & $90.0(9.50)$ & $58.30(7.67)$ \\
\hline Imazethapyr@100 g ha ${ }^{-1}(\mathrm{PoE})$ & $39.0(6.27)$ & $41.70(6.49)$ \\
\hline Quizalofop-ethyl@50 g ha ${ }^{-1}$ (PoE) & $64.0(8.02)$ & $54.27(7.39)$ \\
\hline Fluchloralin@0.75 $\mathrm{kg} \mathrm{ha}^{-1}$ (PPI) $f b$ hoeing at 35 DAS & $42.0(6.51)$ & $46.20(6.83)$ \\
\hline Pendimethalin@0.75 kg ha ${ }^{-1}$ (PE) $f b$ hoeing at 35 DAS & $46.0(6.79)$ & $48.27(6.98)$ \\
\hline Quizalofop-ethyl @ $40 \mathrm{~g} \mathrm{ha}^{-1}$ (PoE) $f b$ hoeing at 35 DAS & $19.0(4.34)$ & $38.60(6.26)$ \\
\hline Imazethapyr@75 $\mathrm{g} \mathrm{ha}^{-1}(\mathrm{PoE}) f b$ hoeing at 35 DAS & $16.0(4.02)$ & $37.90(6.19)$ \\
\hline $\mathrm{SEm} \pm$ & 0.30 & 0.15 \\
\hline $\mathrm{CD}$ at $5 \%$ & 0.89 & 0.45 \\
\hline
\end{tabular}

*Figures in parenthesis are square root transformed values 
Aradhana Bali et al. / J. Appl. \& Nat. Sci. 9 (1): 539 - 543 (2017)

Table 2. Nutrient uptake by weeds and soybean crop as influenced bydifferent weed management practices.

\begin{tabular}{|c|c|c|c|c|c|c|c|c|c|}
\hline \multirow{3}{*}{ Treatments } & \multicolumn{3}{|c|}{ Nutrient uptake by weeds $\left(\mathrm{kg} \mathrm{ha}^{-1}\right)$} & \multicolumn{6}{|c|}{ Nutrient uptake by crop $\left(\mathrm{kg} \mathrm{ha}^{-1}\right)$} \\
\hline & \multirow{2}{*}{$\mathrm{N}$} & \multirow{2}{*}{$\mathrm{P}$} & \multirow{2}{*}{$\mathrm{K}$} & \multicolumn{2}{|c|}{$\mathrm{N}$} & \multicolumn{2}{|c|}{$\mathrm{P}$} & \multicolumn{2}{|c|}{$\mathrm{K}$} \\
\hline & & & & Grain & Straw & Grain & Straw & Grain & Straw \\
\hline Weedy check & $\begin{array}{l}28.45 \\
(5.37)\end{array}$ & $\begin{array}{c}4.54 \\
(2.24)\end{array}$ & $25.28(5.07)$ & 52.79 & 9.76 & 3.54 & 1.84 & 8.38 & 32.67 \\
\hline Weed free & $\begin{array}{c}0.00 \\
(0.71)\end{array}$ & $\begin{array}{c}0.00 \\
(0.71)\end{array}$ & $0.00(0.71)$ & 100.66 & 20.85 & 14.62 & 3.77 & 19.80 & 59.40 \\
\hline $\begin{array}{l}\text { Hand weeding at } 15 \text { and } 35 \\
\text { DAS }\end{array}$ & $\begin{array}{c}5.40 \\
(2.43)\end{array}$ & $\begin{array}{c}0.76 \\
(1.12)\end{array}$ & $4.81(2.30)$ & 98.47 & 19.79 & 13.23 & 3.63 & 19.25 & 58.36 \\
\hline Hoeing at 15 and 35 DAS & $\begin{array}{c}5.94 \\
(2.54)\end{array}$ & $\begin{array}{l}0.95 \\
(1.20)\end{array}$ & $5.29(2.41)$ & 85.28 & 16.09 & 11.41 & 3.10 & 16.12 & 51.12 \\
\hline $\begin{array}{l}\text { Fluchloralin @ } 1.0 \mathrm{~kg} \mathrm{ha}^{-1} \\
\text { (PPI) }\end{array}$ & $\begin{array}{c}9.10 \\
(3.09)\end{array}$ & $\begin{array}{c}1.46 \\
(1.39)\end{array}$ & $8.10(2.93)$ & 70.73 & 13.35 & 6.72 & 2.54 & 12.35 & 43.02 \\
\hline $\begin{array}{l}\text { Pendimethalin@1.0 } \mathrm{kg} \mathrm{ha}^{-1} \\
\text { (PRE) }\end{array}$ & $\begin{array}{c}9.56 \\
(3.17)\end{array}$ & $\begin{array}{c}1.53 \\
(1.42)\end{array}$ & $8.49(2.99)$ & 67.53 & 12.99 & 6.55 & 2.49 & 12.20 & 41.90 \\
\hline $\begin{array}{l}\text { Imazethapyr @ } 100 \mathrm{~g} \mathrm{ha}^{-1} \\
\text { (PoE) }\end{array}$ & $\begin{array}{c}6.94 \\
(2.73)\end{array}$ & $\begin{array}{c}1.11 \\
(1.27)\end{array}$ & $6.18(2.58)$ & 66.51 & 12.78 & 6.34 & 2.41 & 11.51 & 41.70 \\
\hline $\begin{array}{l}\text { Quizalofop-ethyl @ } 50 \mathrm{~g} \mathrm{ha}^{-1} \\
\text { (PoE) }\end{array}$ & $\begin{array}{c}8.34 \\
(2.97)\end{array}$ & $\begin{array}{l}1.36 \\
(1.36)\end{array}$ & $7.43(2.82)$ & 74.43 & 14.12 & 8.18 & 2.73 & 13.49 & 45.38 \\
\hline $\begin{array}{l}\text { Fluchloralin@ } 0.75 \mathrm{~kg} \mathrm{ha}^{-1} \\
\text { (PPI) } f b \text { hoeing at } 35 \text { DAS }\end{array}$ & $\begin{array}{l}7.15 \\
(2.76)\end{array}$ & $\begin{array}{l}1.14 \\
(1.28)\end{array}$ & $6.36(2.62)$ & 83.55 & 16.05 & 10.06 & 3.03 & 15.57 & 50.45 \\
\hline $\begin{array}{l}\text { Pendimethalin@ } 0.75 \mathrm{~kg} \mathrm{ha}^{-1} \\
\text { (PE) } f b \text { hoeing at } 35 \mathrm{DAS}\end{array}$ & $\begin{array}{l}7.62 \\
(2.85)\end{array}$ & $\begin{array}{c}1.21 \\
(1.31)\end{array}$ & $6.75(2.69)$ & 81.97 & 15.67 & 9.51 & 3.02 & 15.04 & 49.96 \\
\hline $\begin{array}{l}\text { Quizalofop-ethyl @ } 40 \mathrm{~g} \mathrm{ha}^{-1} \\
\text { (PoE) } f b \text { hoeing at } 35 \mathrm{DAS}\end{array}$ & $\begin{array}{c}5.74 \\
(2.49)\end{array}$ & $\begin{array}{c}0.92 \\
(1.19)\end{array}$ & $5.11(2.36)$ & 94.27 & 18.66 & 11.84 & 3.45 & 18.03 & 56.21 \\
\hline $\begin{array}{l}\text { Imazethapyr @ } 75 \mathrm{~g} \mathrm{ha}^{-1} \\
\text { (PoE) } f b \text { hoeing at } 35 \mathrm{DAS}\end{array}$ & $\begin{array}{c}5.55 \\
(2.46)\end{array}$ & $\begin{array}{c}0.88 \\
(1.17)\end{array}$ & $4.96(2.33)$ & 96.89 & 19.29 & 12.52 & 3.56 & 18.67 & 57.52 \\
\hline $\mathrm{SEm} \pm$ & 0.07 & 0.02 & 0.06 & 4.17 & 0.78 & 1.05 & 0.14 & 0.86 & 2.45 \\
\hline $\mathrm{CD}$ at $5 \%$ & 0.21 & 0.08 & 0.18 & 12.24 & 2.34 & 3.10 & 0.43 & 2.52 & 7.20 \\
\hline
\end{tabular}

weeds.

The maximum N, P and $\mathrm{K}$ uptake by seed and straw were recorded in weed free which was statistically at par with twice hand weeding at 15 and 35 DAS, imazethapyr@75 $\mathrm{g} \mathrm{ha}^{-1} \mathrm{fb}$ hoeing at 35 DAS and quizalofop-ethyl@40 g ha ${ }^{-1} f b$ hoeing at 35 DAS. Among the herbicide treatments, maximum uptake by seed and straw was recorded in imazethapyr@ $95 \mathrm{~g} \mathrm{ha}^{-1} \mathrm{fb}$ hoeing at 35 DAS which was found to be statistically at par with quizalofop-ethyl @ $40 \mathrm{~g} \mathrm{ha}^{-1} \mathrm{fb}$ hoeing at 35 DAS. The reason might be due to reduced weed flushes at later stages of crop growth which provided favorable environment for crop thus resulted in increased nutrient uptake in favor of crop (Table 2). Similar results were found by Chaphale et al. (2003) and Kumar and Das (2008). Chaphale et al. (2003) reported that the maximum uptake of $\mathrm{N}, \mathrm{P}$ and $\mathrm{K}$ by crop was recorded in pre-emergence application of pendimethalin (a) $1.0 \mathrm{~kg} / \mathrm{ha}+$ one hoeing at 40 DAS than weedy check in soybean crop as early flushes of grassy weeds were reduced by pendamethalin while later flush of weeds were controlled with hoeing at 40 DAS. Kumar and Das (2008) found that herbicides used in combination with hoeing produced significantly better results than herbicides used alone as less nutrient uptake was found with integrated methods than herbicide applied alone. The reason might be the combination of hoeing at 35 DAS which reduced weed dry matter at later stages.
Crop growth and yield attributes: Crop growth attributes were significantly affected by different weed control treatments (Table 3) as compared to weedy check. The highest plant height was observed in weed free which found at par with hand weeding at 15 and 35 DAS, imazethapyr@75 $\mathrm{g} \mathrm{ha}^{-1}$ and quizalofop-ethyl (a) $40 \mathrm{~g} \mathrm{ha}^{-1}$ in combination with hoeing at 35 DAS. The reason might be due to reduced competition by weeds resulted in better availability of nutrients for crop growth which leads to more accumulation of photosynthates. Similar result has been reported by Dhane et al. (2010). Dhane et al. (2010) found that imazethapyr@100g/ha + one HW at 45 DAS produced highest growth parameters and yield attributes as compare to fluchloralin@1kg/ha + one HW at 30 DAS and pendimethalin@1kg/ha + one HW at 30 DAS as it suppressed grassy weeds effectively in soybean crop. The maximum number of branches plant ${ }^{-1}$ was found in weed free which was statistically at par with handweeding at $15 \& 35$ DAS. However, highest number of pods was recorded in weed free which was statistically at par with hand weeding at 15 and 35 DAS, imazethapyr@75 $\mathrm{g} \mathrm{ha}^{-1}$ and quizalofop-ethyl@40 $\mathrm{g} \mathrm{ha}^{-1}$ in combination with hoeing at 35 DAS. It might be due to increased nutrient and moisture availability to the soybean crop due to reduction in dry matter production by weeds under herbicidal and cultural treatments (hoeing). Similar findings were reported by Gupta and Saxena (2008) and Dhane et al. (2010). Gupta and 
Table 3. Effect of different weed management practices on plant height, number of branches plants ${ }^{-1}$, number of pods plants $^{-1}$, seed and straw yield of soybean.

\begin{tabular}{|c|c|c|c|c|c|}
\hline Treatments & $\begin{array}{l}\text { Plant height } \\
(\mathrm{cm})\end{array}$ & $\begin{array}{c}\text { Number of } \\
\text { branches plant }^{-1}\end{array}$ & $\begin{array}{l}\text { Number of } \\
\text { pods plant }^{-1}\end{array}$ & $\begin{array}{l}\text { Seed yield } \\
\left(\mathrm{q} \mathrm{ha} \mathrm{ha}^{-1}\right)\end{array}$ & $\begin{array}{c}\text { Straw yield } \\
\left(\mathrm{q} \text { ha }^{-1}\right)\end{array}$ \\
\hline Weedy check & 89.40 & 2.63 & 77.77 & 9.03 & 15.07 \\
\hline Weed free & 127.73 & 5.22 & 128.90 & 15.52 & 25.92 \\
\hline Hand weeding at $15 \& 35$ DAS & 119.90 & 4.70 & 125.27 & 15.28 & 25.52 \\
\hline Hoeing at $15 \& 35$ DAS & 106.37 & 4.13 & 106.37 & 13.44 & 22.45 \\
\hline Fluchloralin@1.0 kg ha ${ }^{-1}$ (PPI) & 99.70 & 3.30 & 95.37 & 11.61 & 19.40 \\
\hline Pendimethalin@1.0 kg ha ${ }^{-1}(\mathrm{PE})$ & 97.63 & 3.33 & 93.83 & 11.30 & 18.88 \\
\hline Imazethapyr@100 g ha ${ }^{-1}(\mathrm{PoE})$ & 92.32 & 3.10 & 92.87 & 11.18 & 18.67 \\
\hline Quizalofop-ethyl @ $50 \mathrm{~g} \mathrm{ha}^{-1}$ (PoE) & 103.07 & 3.43 & 97.07 & 12.02 & 20.08 \\
\hline $\begin{array}{l}\text { Fluchloralin@0.75 kg ha-1 (PPI) } f b \text { hoeing } \\
\text { at } 35 \text { DAS }\end{array}$ & 105.27 & 3.87 & 105.07 & 13.27 & 22.16 \\
\hline $\begin{array}{l}\text { Pendimethalin@ } 0.75 \mathrm{~kg} \mathrm{ha}^{-1}(\mathrm{PE}) f b \text { hoeing } \\
\text { at } 35 \text { DAS }\end{array}$ & 102.20 & 3.57 & 104.47 & 13.13 & 21.93 \\
\hline $\begin{array}{l}\text { Quizalofop-ethyl @ } 40 \mathrm{~g} \mathrm{ha}^{-1} \text { (PoE) } f b \text { hoe- } \\
\text { ing at } 35 \text { DAS }\end{array}$ & 116.13 & 4.33 & 118.30 & 14.76 & 24.66 \\
\hline $\begin{array}{l}\text { Imazethapyr @ } 75 \mathrm{~g} \mathrm{ha}^{-1} \text { (PoE) } f b \text { hoeing at } \\
\text { 35 DAS }\end{array}$ & 118.08 & 4.43 & 122.23 & 15.08 & 25.19 \\
\hline $\mathrm{SEm} \pm$ & 6.26 & 0.21 & 6.10 & 0.65 & 1.08 \\
\hline $\mathrm{CD}$ at $5 \%$ & 18.36 & 0.64 & 17.89 & 1.9 & 3.18 \\
\hline
\end{tabular}

Saxena (2008) reported that quizalofop-ethyl@0.05 $\mathrm{kgha}^{-1}$ produced highest growth parameters and yield attributes as compared to pendamethalin @ $1 \mathrm{kgha}^{-1}$ in soybean crop as it is very efficient in suppressing monocot weeds whereas, Dhane et al. (2010) found that imazethapyr@100g/ha + one HW at 45 DAS produced highest growth parameters and yield attributes as compare to fluchloralin @ 1kg/ha + one HW at 30 DAS and pendimethalin @ 1 kg/ha + one HW at 30 DAS as it suppressed grassy weeds effectively in soybean crop.

Seed and straw yield: The highest seed and straw yield was obtained with weed free treatment followed by hand-weeding at $15 \& 35$ DAS (Table 3). Among various herbicidal weed control treatments, imazethapyr @ $75 \mathrm{~g} \mathrm{ha}^{-1} f b$ hoeing (35 DAS) recorded higher seed and straw yield which was found to be at par with quizalofop-ethyl@ @ $40 \mathrm{~g} \mathrm{ha}^{-1} \mathrm{fb}$ hoeing (35 DAS). It might be due to the fact that both these herbicides suppresses the weed growth efficiently which is supplemented by hoeing at the crucial stage of crop growth which checks the weed growth and resulted in higher seed and straw yield. Similar findings have been reported by Dhane et al (2010) and Wadafale et al. (2011). Dhane et al (2010) concluded that imazethapyr@100g/ha + one HW at 45 DAS was found to be best treatment as compare to fluchloralin@ @ $1 \mathrm{~kg} / \mathrm{ha}$ + one HW at 30 DAS and pendimethalin @ $1 \mathrm{~kg} / \mathrm{ha}+$ one HW at 30 DAS in suppressing grassy weeds effectively in soybean crop. Wadafale et al. (2011) resulted that the grain and straw yields obtained with two hoeings and two hand weedings at 20 DAS and 35 DAS were at par with the application of imazethapyr (a) $75 \mathrm{~g}$ a.i. ha ${ }^{-1}$ at $15 \mathrm{DAS}+$ one hoeing and one hand weeding at 35 DAS.

Weed's predominance in area depends on weed seed ecology. There is variation in agro-climatic zones of India and thus dominance of weeds in a region varies from other. Soybean crop has been introduced for the first time into the research field in the Jammu region. Due to novelty of crop and different agro-climatic zone, experiment has been planned to study the impact of weeds and their management in soybean. Soybean crop has been used due to its multiple uses and thus could be brought into mainland farming after evaluating it in the research farm. It has been found that grassy and annual broad weeds had more dominance as compared to sedges and BLWs in soybean crop in Jammu region. Moreover, imazethapyr and quizalofopethyl were found to be efficient in controlling broad range of weeds (grasses, sedges and BLWs) as compare to others. However, alone application of imazethapyr@100 g/ha also showed phytotoxic effect on crop growth as observed visually in the field. Mechanical hoe has been used in the experiment as a mechanical measure to manage weeds which was highly efficient in uprooting the inter-row weeds while saving time, labour and energy as compared to hand-weeding.

\section{Conclusion}

It was concluded that nutrient uptake by weeds was found to be lowest with the application of imazethapyr (a) $75 \mathrm{~g} \mathrm{ha}^{-1} \mathrm{fb}$ one hoeing at 35 DAS and quizalofop @ $40 \mathrm{~g} \mathrm{ha}^{-1} \mathrm{fb}$ one hoeing at 35 DAS with the integration of hoeing at 35 DAS. Imazethapyr @ $75 \mathrm{~g} \mathrm{ha}^{-1} \mathrm{fb}$ one hoeing at 35 DAS and quizalofop-ethyl @ $40 \mathrm{~g} \mathrm{ha}^{-1} \mathrm{fb}$ one hoeing at 35 DAS were found to be best treatments to manage weeds effectively and to obtain maximum yield.

\section{ACKNOWLEDGEMENTS}

The author sincerely acknowledges SKUAST-Jammu 
for the financial support in the form of scholarship for M.Sc. research. Thanks are also due to the Head and Professor for providing field and laboratory facilities at the Division of Agronomy, SKUAST-Jammu during the course of this investigation. My utmost gratitude is towards Mr. Sandeep Rawal, Ph.D Scholar, who helped in drafting and correcting this paper.

\section{REFERENCES}

Chaphale, S.D., Kuchanwar, O.D., Chamate, N.W. and Chafle, B.S. (2003). Effect of weed management on nutrientuptake of soybean and soil properties. Journal of Soils and Crops, 13: 179-181.

Dhane, J. B., Jawale, S. M., Shaikh, A. A., Dalavi, N. D. and Dalavi, P. N.(2010). Effec $t$ of integrated weed management on yield and quality of soybean (Glycinemax L.). Journal of Maharashtra Agricultural Universities, 35: 322-325.

Gupta, A. and Saxena, S. C. (2008). Weed management in soybean (Glycine max L.) in Tarai region of Uttarakhand to sustain productivity. Pantnagar Journal of Research, 6: 1-5.

Kumar, M. and Das, T. K. (2008).Integrated weed management for system productivity and economics in soybean
(Glycinemax)-wheat (Triticumaestivum) system. Indian Journal of Agronomy, 53: 189-194.

Meena, D. S. and Jadon, C. (2009). Effect of integrated weed management on growth and yield of soybean (Glycinemax). Current Advances in Agricultural Sciences, 1: 50-51.

Mishra, J. S., Singh, V. P. and Yaduraju, N. T. (2002). Interference of common day flower (Commelinabengalensis L.) in soybean (Glycine max. L.). Indian Journal of Weed Science, 34: 295-296.

Jackson, M. L. (1973). Soil chemical analysis, pp 165 -167. Asia Publication House, Bombay.

Olsen, S. R., Cole, C.W., Watanade, F. S. and Dean, L. A. 1954. Estimation of available phosphorus of soil by extraction with $\mathrm{NaHCO}_{3}$. U. S. D. A., Circular No. 939.

SOPA (2014). Estimates of area, productivity \& production of Soybean in India during kharif (monsoon). The Soybean Processors Association of India (SOPA).

Subbaiah, B. V. and Asija, G. L. (1956). A rapid procedure for the estimation of available nitrogen in soil. Current Science, 25: 250-260.

Vyas, M. D., Jain, R. C. and Dubey, S. (2003). Productivity and weed control efficiency of integrated weed management practices in pigeonpea+soybean intercropping system under rainfed condition. Indian Journal of Weed 